\title{
DASHBOARD VISUALISATION FOR HEALTHCARE PERFORMANCE MANAGEMENT: BALANCED SCORECARD METRICS
}

\author{
Stephen Victorl, Ayesha Farooq ${ }^{2}$ \\ 1. Punjab College of Technical Education (PCTE), Ludhiana, India \\ 2. Aligarh Muslim University(AMU), Aligarh, India
}

Correspondence: stephenvictor77@gmail.com

\begin{abstract}
OBJECTIVE:

The increase in demand for hospitalisation in an environment of financial stress has hastened the quest for more efficient healthcare delivery systems. In the past performance management methodologies in the healthcare sector have been predominantly static resulting in a lack of consistency, comparability and timeliness. To mitigate these shortcomings this research work has attempted to create a conceptual framework in the digital dashboard format.
\end{abstract}

SETTING:

Of the frameworks presently used, the Balanced Scorecard(BSC) is very popular, primarily because the BSC is a management system (not just a measurement system) that helps an organization highlight its vision and translate them into action.

\section{DESIGN:}

The design adopted in this research work is primarily qualitative and exploratory. The methodology includes collating KPIs from published literature, crystallising them using the Delphi Method and applying the Likert-scale to prioritise them. To facilitate visualisation of the prioritised KPIs in the BSC format, the construction of a digital dashboard was envisaged.

\section{RESULTS:}

A dynamic dashboard was created in the BSC format with three Key Performance Indicators(KPI) for each of the four perspectives.

1. Financial: Return on assets, average daily collections and working capital ratio

2. Customer Perspective: Patient satisfaction, lost business - number of appointments not attended and percentage of patients Leaving Against Medical Advice(LAMA)

3. Internal Processes: Billing and collections/posting time, emergency patients triaged within 15 minutes of arrival and patient waiting time

4. Learning And Growth: Empowerment (decision-making \& participation), employee satisfaction and strategic alliances/partnerships

\section{KEYWORDS}

Dashboard, Balanced Scorecard (BSC), Key Performance Indicators (KPI), Performance Management, Healthcare 
INTRODUCTION

The success of an organisation depends upon how its performance is managed. Very often, Healthcare administrators are unable to view with clarity the overall picture of performance. The complicated nature of healthcare operations is a hindrance to managers to effectively support the organization's objectives. The data for healthcare management which exists in a wide variety of forms also needs to be analysed and managed across health service functions and departments. This diversity leads to several challenges in managing healthcare operations to the extent that it is widely acknowledged and described by Gartner Research, a group of IT industry analysts as "data-rich, but information poor." [1] The cause of this poor state could be a combination of the following with varying degrees of influence:

- different software packages used for patient admissions, treatments and discharges.

- financial package variations in billing and claims

- varied data formats for clinical diagnosis, research and laboratory tests

These factors may not provide administrators and managers with a clear view of an organisation's performance. Focus on financial performance alone is grossly inadequate to enhance the overall performance of an organisation. Non-financial measures like customer expectations and internal efficiencies too clearly influence the performance. Over the years, the Balanced Scorecard (BSC) has been frequently applied both in academic and corporate circles as a performance management tool. [2] The BSC has been very successful because of its balanced approach between financial and non-financial indicators of success, internal and external constituents of the organization, and lag and lead indicators of performances. [3)

Using the BSC framework, dashboard visualisations were created for the Christian Medical College and Hospital $(\mathrm{CMCH})$, Ludhiana, Punjab, in close coordination with their administrators during the period 2017-20. Established in $1894, \mathrm{CMCH}$ is one of the leading Medical Colleges in the North of India.

\section{REVIEW OF LITERATURE}

\section{DASHBOARD VISUALISATION}

The utility of the dashboard has enormously increased due to its ability to enable decision-makers to navigate in the ever-growing complex data environment. Advanced versions of dashboards are interactive and these can drill i.e. help slice and dice, blending with data. [4] Dashboards usher in a wide epistemological and internal realignment in that they introduce new vistas of knowledge for monitoring. [5] Visualisation has its benefits. As Rind suggests, visualization methodologies and tools, "combine the processing power of modern computers with human cognition and visual abilities to better support analysis task". [6]

The advancements in visual formatting techniques add to the interactive nature of the dashboard. Novel features like drill-down facility, outlier detection and scenario analysis with appropriate high-end visual displays greatly enhance decision-support systems. [7] The primary benefit of dashboards lies in the convenient form they display crucial pieces of data that will lead to quick decision-making, cost reductions and superior confidence levels (8).

In an environment of complex data and emerging technologies, there are certain considerations to be kept in mind while developing high-tech performance management dashboards for hospitals. According to Ghazisaeidi, these issues are, "KPIs development, data sources, data quality, dashboards integration to source systems and data presentation to users". [7] Harrington et al. have inferred that "key performance indicators, balanced scorecards, and sales performance figures are some of the content appropriate on dashboards". [10]

Creating a BSC Dashboard requires defining all metrics after a clear understanding of each metric including its nomenclature, purpose, target values, ranges, measurement units, periodicity of reporting, and sourcing of data. [11] Since the hosting of data is done in different structures, an appropriate architecture can be designed and implemented. This involves managing data delivery, data replication methods, understanding data hosting and query formulation that leads to the construction of effective dashboards. [12]

\section{BALANCED SCORECARD}

Under Dr. Nolan Norton's leadership, a study was conducted by a consulting company in 1990-1991 to determine what successful companies were measuring. [13] As a result of this study, the Balanced Scorecard was 
proposed in its initial form. In addition to this Professor Robert Kaplan (Harvard Business School), was inducted into the research team to provide educational support. The timing of creating and presenting the Balanced Scorecard perfectly suited the quest for performance management systems. Eccles (1991) published the "Performance Measurement Manifesto" in the Harvard Business Review. In this article, he predicted, "a performance measurement revolution will take place in the next five years, during which traditional financial information systems would be replaced by non-financial information systems". [14]

The "Scorecard" comprises of targets and measures for each of the four components of the framework namely, Financial, Customer, Internal Business Processes and Learning and Growth. Each organisation should decide on three or four "Key Performance Indicators (KPI)" based on scientific principles and arrive at target values for the KPIs.

\section{FIGURE 1: BALANCED SCORECARD}

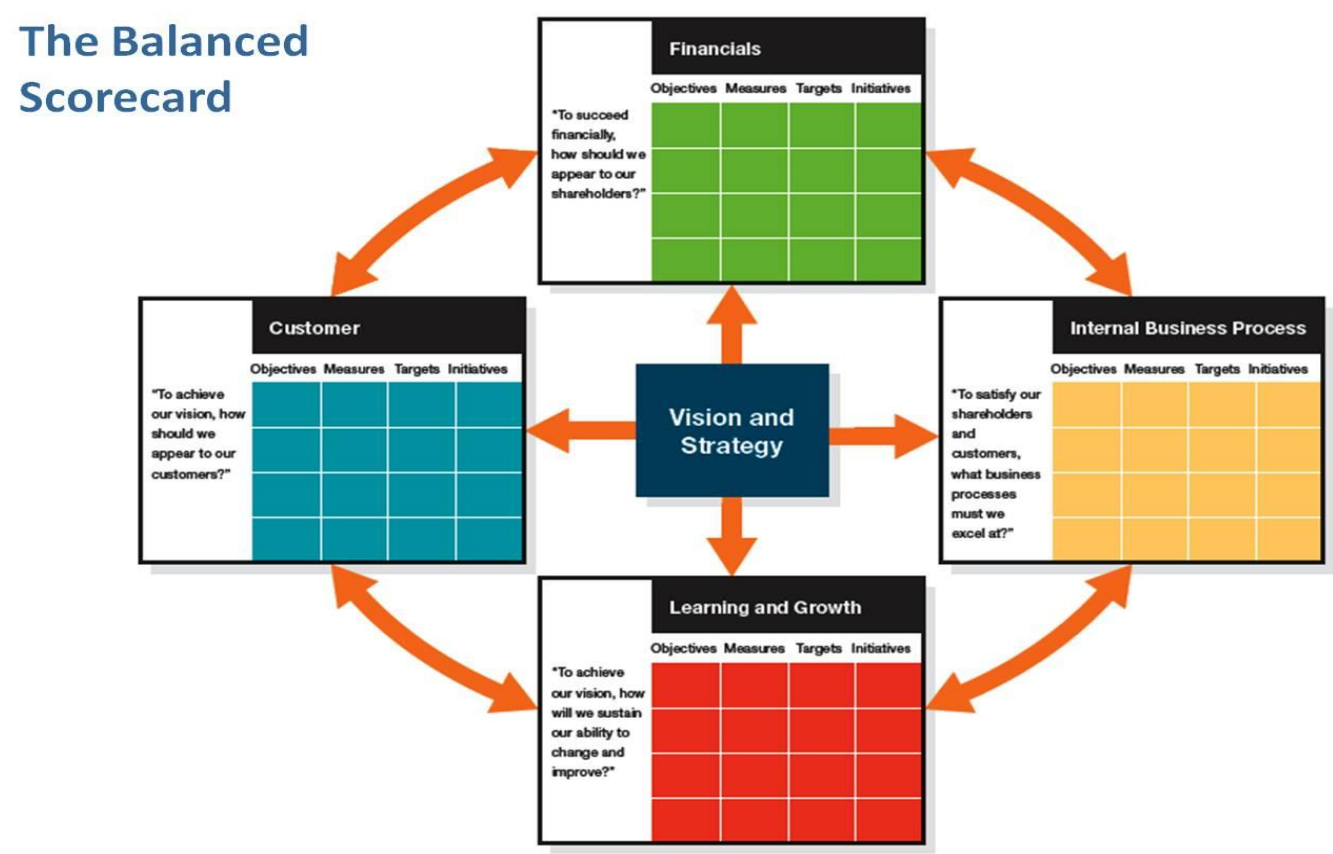

Source: Linking the Balanced Scorecard to Strategy (15)

According to a study conducted by Bain \& Co., the global consulting firm, $57 \%$ of companies had benefited from BSC implementation with a Satisfaction Index of 3.86 on a scale of 5. [16] When the BSC is integrated with the dashboard, it ushers in an innovative way of reasoning and operating that is well suited in enhancing healthcare delivery. The dynamic BSC allows an organization to set targets, link metrics, understand the correlation among metrics, and easily view trends. Ideally, the metrics are linked to an organization's overall strategy. BSC implementations are seen to reduce ambiguities in performance evaluations and increase goal congruence between the various groups within the organisation. [17]

\section{BSC IN HEALTHCARE}

Each perspective of the BSC can be applied to benefit the management of healthcare organizations. Looking at the BSC from the healthcare management point of view, Končitíková, Culík and Pavla have given a specific definition as: "How patients perceive an organization (Customer perspective); what are financial situations (Financial Perspectives); what can we do to improve the level of services? (Perspective of learning and growth); what do we want to be the best in? (Perspective of internal business processes)". [18] It enables top-level decisionmakers to a have smooth transition from judgments based on experience and intuition to fact-based decisions based on the healthcare BSC.

The BSC and the dashboard combination can be adopted as a model for cost-effective yet credible healthcare delivery. A notable study conducted by Chow provided insight regarding the benefits of using the BSC by healthcare organizations. This study documented the potential of the BSC as a management tool to meet many challenges like "changing demographics, increased customer expectations, increased competition, and intensified governmental pressure". [19] 


\section{KEY PERFORMANCE INDICATOR (KPI)}

The BSC relies heavily on the concept of Key Performance Indicators (KPI). "KPI is a quantifiable measure used to evaluate the success of an organization, employee etc. in meeting objectives for performance". [20] Operational excellence can be directly correlated with KPIs which enable measuring and monitoring relevant parameters. [21]. The measurement of KPIs can be done at different levels in the organisation to ensure that targets are successfully achieved. High-level KPIs may focus on the overall performance of the business, while low-level KPIs may focus on separate processes that make up for the corporate entity. [22)

KPIs play a crucial role in planning, evaluating and controlling through information support, transparency creation and decision-making support of the management (23). Some of the major benefits of performance measures are in creating action plans and making daily decisions that are linked and aligned to the factors that will bring success to the organization. Overall performance gets enhanced when "Wider ownership, empowerment, and fulfilment are created". [19]

\section{RESEARCH METHODOLOGY}

\section{STAGE 1: COLLATION OF KPIS FROM PUBLISHED LITERATURE}

In the first stage, many research publications related to Balanced Scorecard in Healthcare settings were studied. This included documented cases of gainful implementation, suggested modifications and identification of successful KPIs. The search criteria were Healthcare Balanced Scorecard, Key Performance Indicators in Hospitals/Healthcare Institutions, Healthcare Performance Management. Institutions with less than 100 beds were excluded.

\section{STAGE 2: USING THE DELPHI METHOD TO CRYSTALLISE KPIS}

In the second stage, the Delphi Technique, which is one of the most effective tools used for qualitative research within a specific domain of expertise was used. [25] The minimum number of participants recommended for a Delphi group is five. [26] The criterion of choosing was to include experts who have had several decades of experience in specific fields like Clinical, Finance, Operations etc. All of them had sufficient administrative experience in managing large healthcare facilities. Their details are:
1. Dr. J. Pramod-Ex-Director, CMC Hospital, Ludhiana, Punjab

2. Dr. Sunil Chandy - Ex-Director, CMC Hospital, Vellore, TN

3. Dr. Abraham Joseph - Ex-Director, CIHSR, Dimapur, Nagaland

4. Dr. Lionel-Ex-Medical Suptd. CMC, Vellore, TN

5. Mr. Nandakumar-Internal Audit, CMC, Vellore, TN

The entire list of collated KPIs was presented individually to the Delphi team members. The initial rounds of discussion had queries on a semi-structured format. As part of the preliminary work, healthcare experts identified important KPIs for each of the perspectives. They were encouraged to add or delete KPIs according to their appropriateness. Comments given by the participants were kept in strict confidentiality to ensure non-interference in the opinions. This was followed by the merging and synthesis of opinions to identify the KPIs. To obtain the priority list of KPIs all the experts in the panel participated in a round of short-listing during which they gave their rating of importance on a fivepoint Likert-scale for all KPIs.

\section{STAGE 3: DASHBOARD DEVELOPMENT}

For dashboard development, the cloud-based BSC Designer tool was used. The BSC designer facilitates the preparation of Strategy Maps and Scorecards in the dashboard format. It provides the algorithms for setting and modifying target values for each of the KPIs. Being userfriendly it gives dynamic features like periodic updating and reporting with appropriate visualisations. The inputs required by the BSC Designer are 'business goals', 'KPIs' and figures like 'target value', 'actual value' and 'permissible range'. Display formats available are the gauge, bar chart, pie chart, radar and graph. Data from the IT systems of the hospital are captured and used as inputs into the BSC Designer.

\section{RESULTS}

A representative list of researched literature for KPI identification in healthcare is shown in Table 1 along with the salient KPIs identified.

The initial collation identified $128 \mathrm{KPIs}$ which reduced to 42 after the Delphi round. The break-up for each of the perspectives is shown in Table 2 


\begin{tabular}{|c|c|c|c|}
\hline $\begin{array}{l}\text { SL. } \\
\text { NO. }\end{array}$ & $\begin{array}{l}\text { COUNTRY/ } \\
\text { COUNTRIES }\end{array}$ & PUBLICATION TITLE & SALIENT KPIS IDENTIFIED \\
\hline 1 & CANADA & $\begin{array}{l}\text { "Do hospital balanced scorecard } \\
\text { measures reflect cause-effect } \\
\text { relationships?" (28) }\end{array}$ & $\begin{array}{l}\text { Critical incidents, Commitment to transition } \\
\text { planning and follow-up, Patients who would } \\
\text { recommend to others }\end{array}$ \\
\hline 2 & $\begin{array}{l}\text { CHINA } \\
\text { AND } \\
\text { JAPAN }\end{array}$ & $\begin{array}{l}\text { "Using the balanced scorecard to } \\
\text { measure Chinese and Japanese } \\
\text { hospital performance" (29) }\end{array}$ & $\begin{array}{l}\text { Expenditure on medical research, Asset } \\
\text { turnover, Outpatients per year per doctor }\end{array}$ \\
\hline 3 & U.S. A & $\begin{array}{l}\text { "Bi Application: Dashboards for } \\
\text { Healthcare" (30) }\end{array}$ & $\begin{array}{l}\text { In-patient commercial revenue, Patients } \\
\text { given fibrinolytic medication within } 30 \\
\text { minutes of arrival }\end{array}$ \\
\hline 4 & IRAN & $\begin{array}{l}\text { "Key performance indicators in } \\
\text { hospital based on balanced } \\
\text { scorecard model" (31) }\end{array}$ & $\begin{array}{l}\text { Employee absenteeism rate, Hospital } \\
\text { infection rate, Current cost per bed, Bed } \\
\text { turnover, Training expenditures per capita }\end{array}$ \\
\hline 5 & MALAYSIA & $\begin{array}{l}\text { "Framework for implementing } \\
\text { balanced scorecard in hospitals" } \\
\text { (32) }\end{array}$ & $\begin{array}{l}\text { Asset turnover, Cost per case, Mortality } \\
\text { index, Number of research projects, } \\
\text { Outpatient waiting times }\end{array}$ \\
\hline 6 & TAIWAN & $\begin{array}{l}\text { "Identifying Key Performance } \\
\text { Indicator of Balanced Scorecard by } \\
\text { Analytic Hierarchy Process" (33) }\end{array}$ & $\begin{array}{l}\text { Exploring new markets, Reduction in } \\
\text { overhead, Activity based costing, Utilization } \\
\text { of space, Employee satisfaction, Reduced } \\
\text { rate of no-show }\end{array}$ \\
\hline 7 & GREECE & $\begin{array}{l}\text { "Strategic performance } \\
\text { measurement in a healthcare } \\
\text { organisation: A multiple criteria } \\
\text { approach based on balanced } \\
\text { scorecard" (34) }\end{array}$ & $\begin{array}{l}\text { "Percentage of readmissions, Inventory } \\
\text { turnover, Number of projects with other } \\
\text { organisations, Decrease of operating } \\
\text { expenses, Increase of liquidity" }\end{array}$ \\
\hline 8 & $\begin{array}{l}\text { SAUDI } \\
\text { ARABIA }\end{array}$ & $\begin{array}{l}\text { "Developing strategic health care } \\
\text { key performance indicators: A case } \\
\text { study on a tertiary care hospital" (35) }\end{array}$ & $\begin{array}{l}\text { Average length of stay(ALOS), OR Utilization } \\
\text { Rate, ER waiting time, Outpatient } \\
\text { satisfaction rate, Average bed occupancy } \\
\text { rate }\end{array}$ \\
\hline 9 & ITALY & $\begin{array}{l}\text { "An integrated approach based on } \\
\text { balanced scorecard and analytic } \\
\text { hierarchy process for strategic } \\
\text { evaluation of local healthcare } \\
\text { agencies" (27) }\end{array}$ & $\begin{array}{l}\text { Percentage of patients leaving against } \\
\text { medical advise, Pharmaceutical stock } \\
\text { turnover ratio, Rate of technical } \\
\text { obsolescence }\end{array}$ \\
\hline
\end{tabular}




\begin{tabular}{|l|l|l|l|}
\multicolumn{1}{|c|}{ PERSPECTIVE } & $\begin{array}{l}\text { INITIAL } \\
\text { COLLATION }\end{array}$ & DELPHI ROUND & LIKERT-SCALE \\
\hline FINANCIAL & 33 & 10 & 3 \\
\hline CUSTOMER & 11 & 8 & 3 \\
\hline INTERNAL PROCESS & 59 & 13 & 3 \\
\hline LEARNING AND GROWTH & 25 & 11 & 3 \\
\hline TOTAL & 128 & 42 & 9 \\
\hline
\end{tabular}

The KPIs that were identified are:

I. FINANCIAL

1. Return on assets: Utilisation of each facility

2. Average daily collections: The revenue arising out of hospital operations

3. Working capital ratio: Total current assets by total current liabilities

\section{CUSTOMER PERSPECTIVE}

1. Patient satisfaction: Extent to which patients are happy with the healthcare delivery

2. Lost business - Number of appointments not attended: Patients who fail to turn up after fixing appointments

3. Percentage of patients Leaving Against Medical Advice(LAMA): Dissatisfied patients who are determined to leave the facility at their own risk

\section{INTERNAL PROCESSES}

1. Billing and collections/posting time: The amount of time taken to prepare bills.

2. Emergency patients triaged within 15 minutes of arrival: The speed at which emergency patients are attended to 3. Patient Waiting time: The time taken by the doctor to see the patient

\section{LEARNING AND GROWTH}

1. Empowerment (decision-making \& participation): Freedom given to the employees to make decisions

2. Employee satisfaction: The employee's overall experience with the work and environment

3. Strategic alliances/partnerships: Partnerships made with niche service providers

The BSC developed for the Christian Medical College and Hospital $(\mathrm{CMCH})$ is shown in Figure 2. For each of the perspectives, three prioritised KPIs with the current values are displayed. Display in the BSC format is a handy tool that gives crucial information on a single screen of the hospital's overall performance. Administrators can initiate corrective action based on dashboard visualisations. Additionally, the software also has a provision for alerts that will be sent to the responsible person automatically by email when a KPI value goes beyond a particular upper/lower limit so that course corrections could be made.

\section{LEARNING AND GROWTH PERSPECTIVE}

The relative importance of the three KPIs was calculated and is shown as a Pie Chart in Figure 3. The combined score of the employee-related KPIs is $67.6 \%$, highlighting the importance of human resources. The employee satisfaction level is shown in a gauge format. The green, amber and red zones are shown in the background according to preset limits.

\section{CUSTOMER PERSPECTIVE}

For the customer perspective, a sample dashboard visualisation is shown in Figure 4. These covers 'Patients Leaving Against Medical Advice'(LAMA) and 'Skipped appointments'. The blue line indicates the progress which is monitored based on a monthly average. 'Skipped appointments' is shown in the traffic signal format. Since the number of skipped appointments should be as low as possible, the setting is done in the reversed order. A value higher than the set limit is shown in 'red'.

\section{INTERNAL PROCESSES PERSPECTIVE}

'Emergency Care' is plotted on a graph showing 'probability' on its $\mathrm{X}$-axis and 'Impact' on its $\mathrm{Y}$-axis. See Figure 5. This is a novel feature that helps administrators to interpret the performance and take appropriate action. This KPI is needed to keep track of how well emergency 
patients are triaged within 15 minutes of arrival. It becomes crucial to the success of large hospitals as it influences the perception of care. When patients arriving at the Trauma Centre get immediate care they are satisfied and are likely to become brand ambassadors for the healthcare facility. Since 'Billing Time' should be as low as possible the setting required on the gauge is to be reversed showing green first, followed by yellow, amber and red.

\section{FINANCE PERSPECTIVE}

Figure 6 shows the performance of the 'Average Daily Collection' and 'Working Capital Ratio'. Average Daily
Collection is shown in a graphical form. The red line indicates the baseline figure, the blue indicates the actual performance figure and the green indicates the target figure. It is notable here that all three figures namely baseline, target and actual performance can be modified and updated as required. Working Capital Ratio is represented as a bar chart based on the historical data entered into the database. The colour of the bar changes according to the preset value. A red bar indicates that corrective action needs to be initiated.

\section{FIGURE 2. BALANCED SCORECARD}

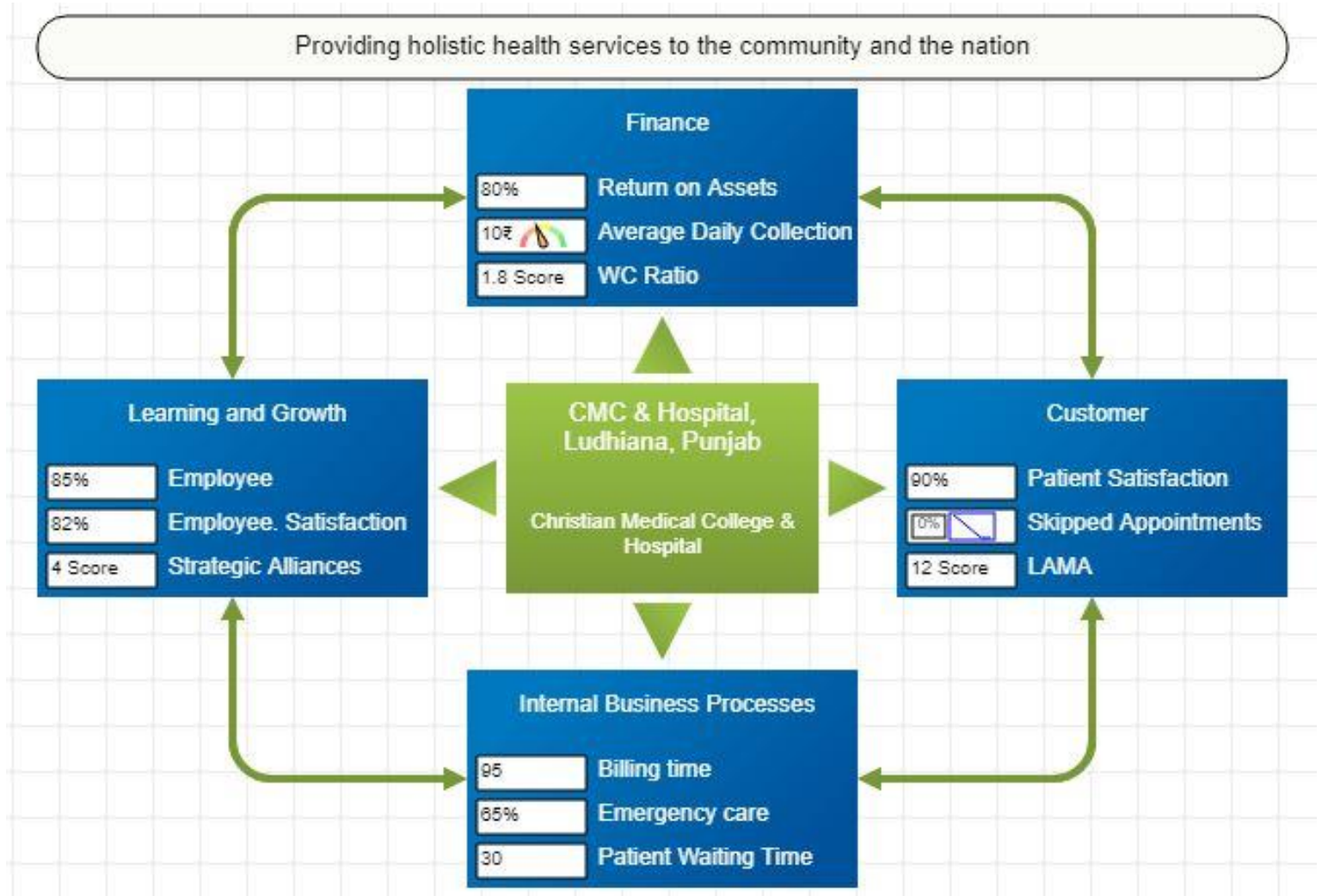

FIGURE 3. LEARNING AND GROWTH PERSPECTIVE

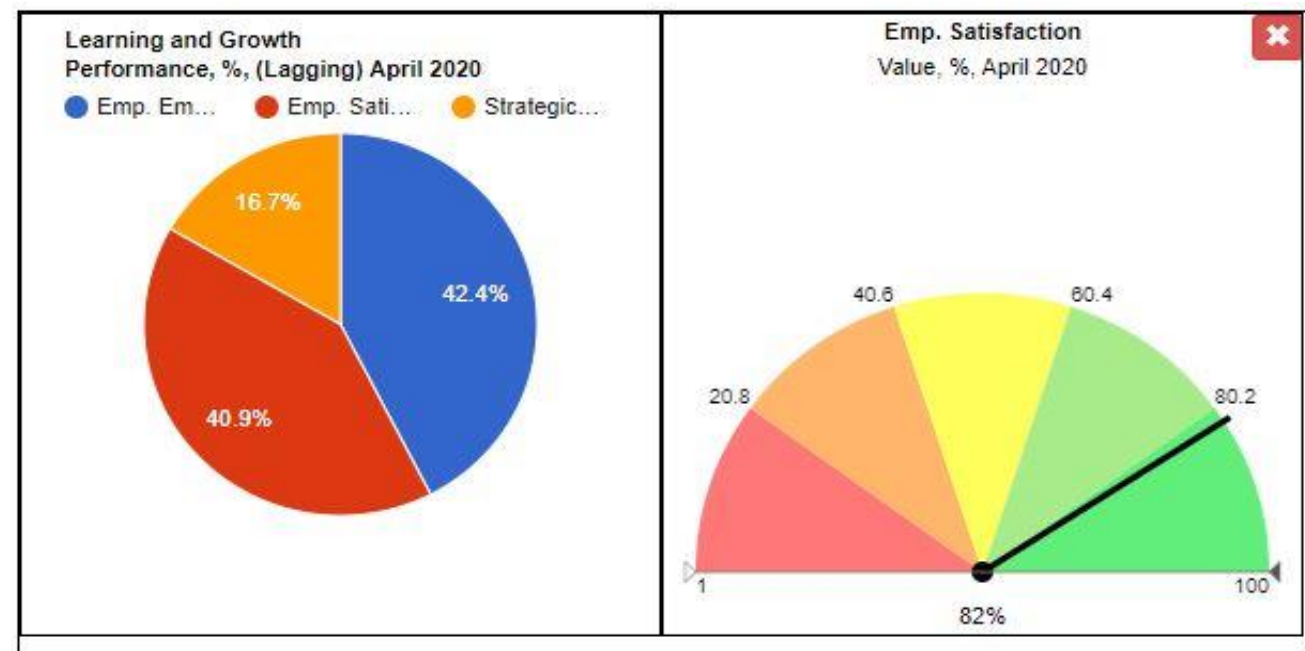




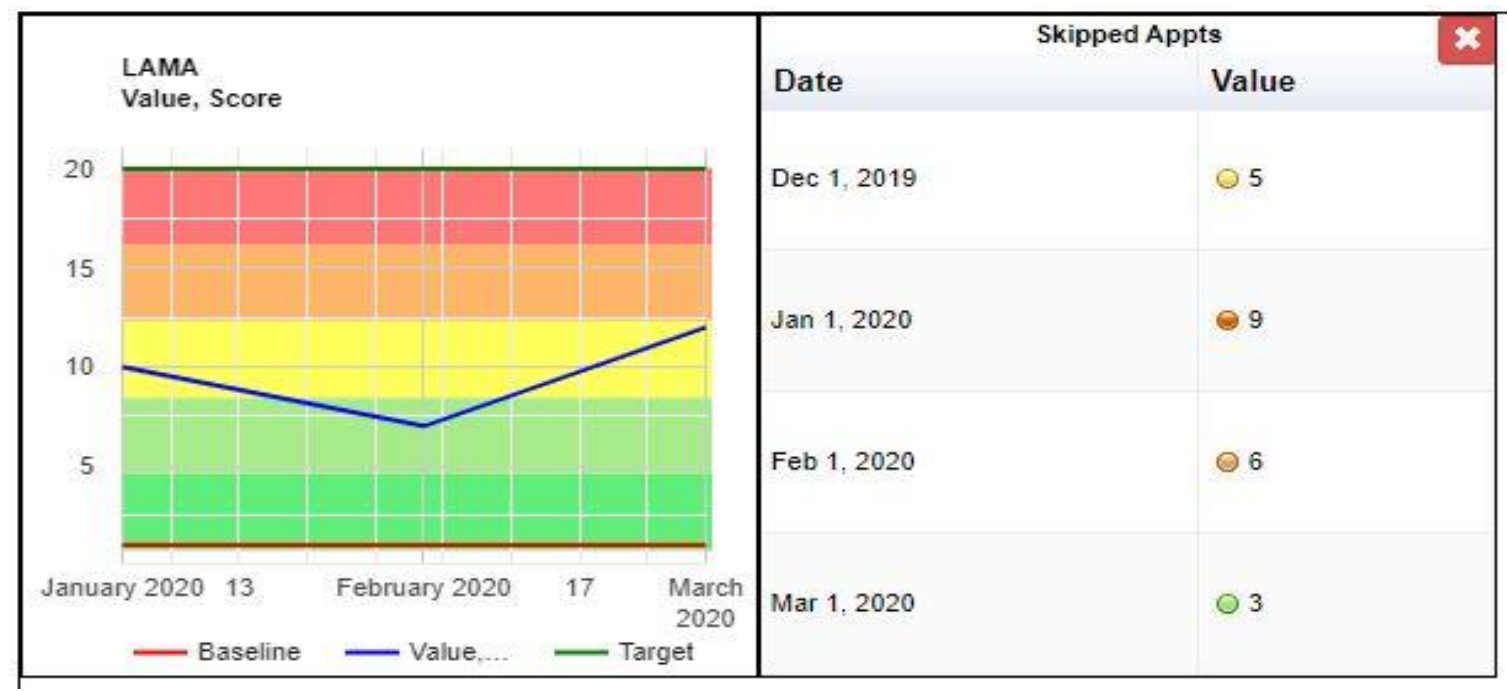

FIGURE 5. INTERNAL PROCESSES PERSPECTIVE

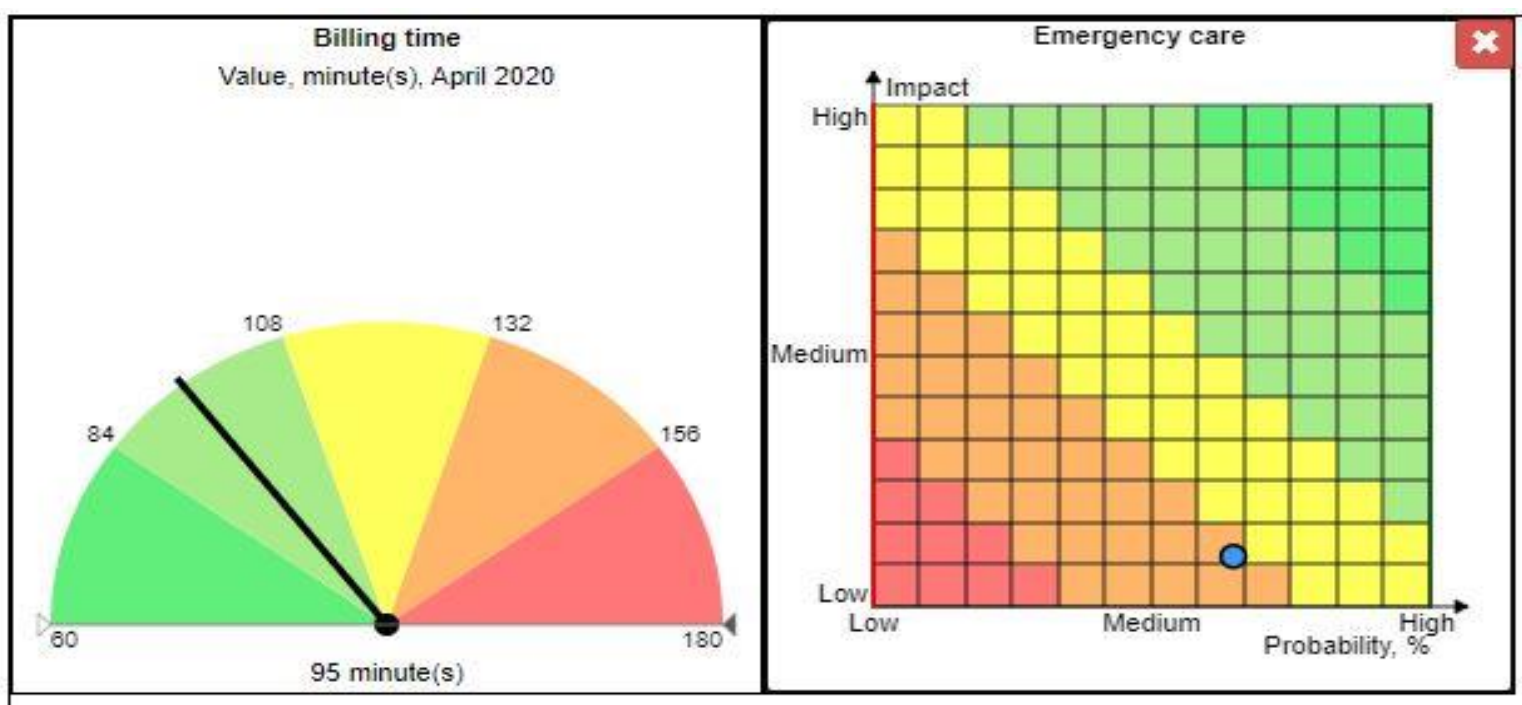

FIGURE 6. FINANCE PERSPECTIVE

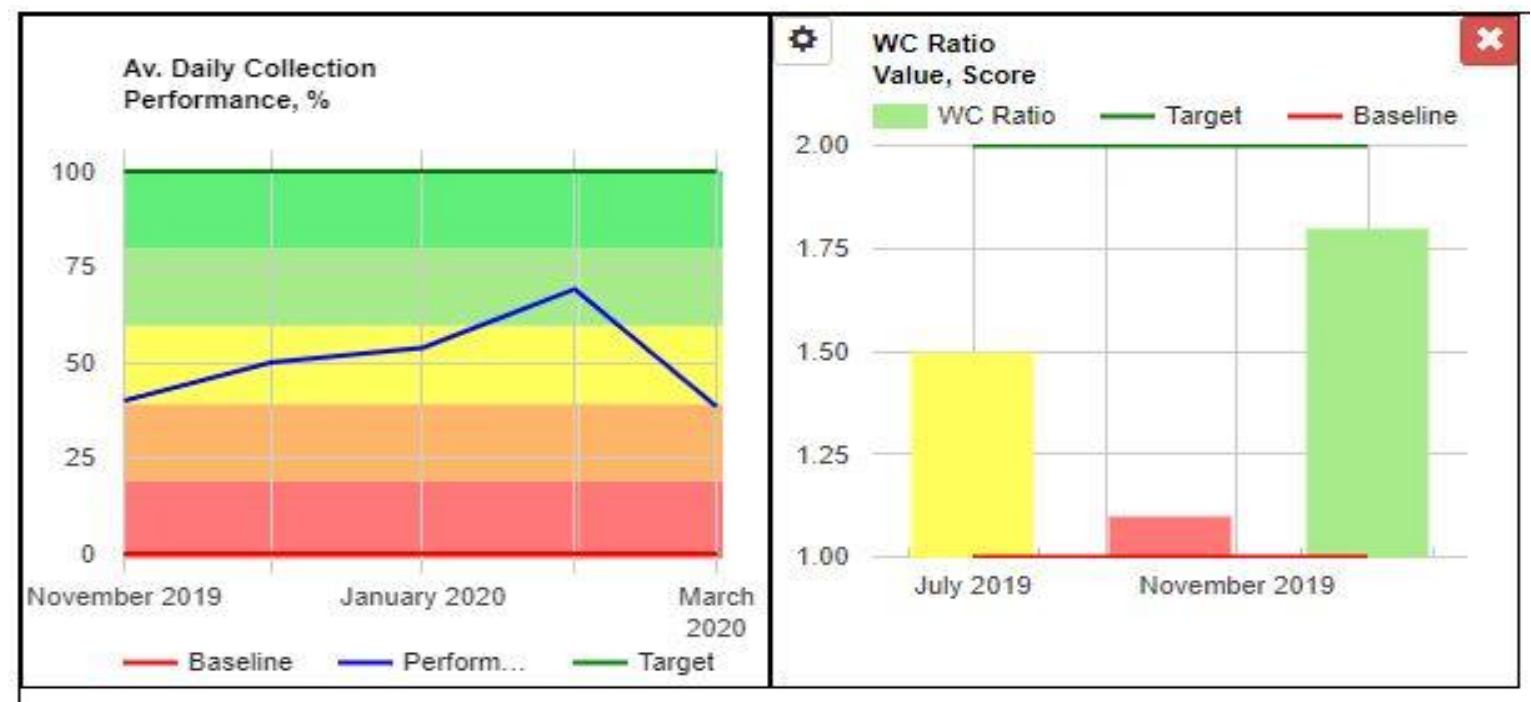


The World Health Organisation (WHO) has taken an initiative to better health standards through its "Health System Metrics (HSM)". This effort aims to provide users with "a minimal set of core indicators, that are comparable between populations and over time, and identify the key measurement issues and strategies required to report regularly on the status of the health system" (36). The HSM sets the tone for data management and transforming data into useful information. The critical need here is the management and presentation of data when crossfunctional needs arise. The research work undertaken has endeavoured to address this important need. The BSC provides an excellent framework that fits this requirement. The Dashboard Visualisation for Healthcare Performance Management using BSC measurement scores over other measurements such as "The Baldrige Excellence Framework (BEF)". The BSC presents crucial decision-aiding information in four different perspectives leaving no gaps in performance parameters while the BEF does not have such classification.

A review of the importance of KPIs will necessitate changes and these changes will require the development of more sophisticated IT systems at the back end. At the front end, dashboards are expected to become more and more user-friendly permitting real-time data updating resulting in more accurate information for decision making. Scope for further research exists in the use of Business Analytics in dashboard applications. This is expected to be helpful in continuous iterative exploration and research of past business performance to gain insight and drive corporate strategy implementations.

\section{LIMITATIONS:}

This work covers the perspectives of respondents within a particular time frame. Since the Indian healthcare scenario is very dynamic with changes occurring frequently, the findings of this study need to be reviewed periodically. Fortunately, the developed BSC lends itself to the required flexibility. Furthermore, the primary data collection was completed before the coronavirus pandemic and hence the views of the experts involved in the Delphi process might be radically different now, which may impact the KPIs chosen.
Combining traditional research methodologies like literature searches, the Delphi method and Likert-scale with versatile software tools, a user-friendly digital dashboard has been developed. Having many modifiable components, the developed BSC framework can serve as a benchmark for further formulation of specialised models for applications in specific areas like diagnostics, clinical services and facility management. The results of this research are expected to be of significance to hospitals looking for best practices in performance management. The outcome of this research adds to the ever-growing broad literature related to Healthcare Performance Management systems.

\section{CONFLICT OF INTEREST:}

The authors declare that there is no conflict of interest.

\section{References}

1. Edwards J. Connecting for Health: The Way Forward in a Time of Radical Change - Gartner Industry Report 7. 2006.

2. Khatoon S, Farooq A. Balanced Scorecard As a Tool To Influence Organizational Performance: Evidences From Indian Companies. Prestige-Journal Manag Res [Internet]. 2014;1 (1). Available from: http://www.pimrindore.ac.in/vol1-issue2-vol2issue 1/Final E-Journal.18-35.pdf

3. Norton DP. What is a good balanced scorecard? Point of view. 03102 ed. Lincoln [MA]: Renaissance Solutions, Inc; 1996.

4. Velcu-Laitinen $O$, Yigitbasioglu OM. The use of dashboards in performance management: Evidence from sales managers. Int J Digit Account Res. 2012;

5. Bartlett J, Tkacz N. Governance by Dashboard A Policy Paper. March 2017. London: Demos; Report No.: ISBN 978-1-9111-10-7.

6. Rind A. Interactive Information Visualization to Explore and Query Electronic Health Records. Found Trends® Human-Computer Interact. 2013;

7. Pauwels K, Ambler T, Clark BH, LaPointe P, Reibstein D, Skiera B, et al. Dashboards as a service: Why, what, how, and what research is needed? J Serv Res. 2009;12(2):175-89. 
8. Sloane E, Rosow E, Adam J, Shine D. Clinical Engineering Department Strategic Graphical Dashboard to Enhance Maintenance Planning and Asset Management. In 2006.

9. Ghazisaeidi M, Safdari R, Torabi M, Mirzaee M, Farzi J, Goodini A. Development of performance dashboards in healthcare sector: Key practical issues. Acta Inform Medica. 2015;23(5):317-21.

10. Harrington L, Hoffman E, Allard PM, Adams BJ, Hamilton $P$, Wright $K$, et al. Nursing research dashboard: A tool for managing your nursing research program. Nurse Lead. 2006;

11. Lempinen $\mathrm{H}$. Constructing a design framework for performance dashboards. In: Lecture Notes in Business Information Processing. 2012.

12. Nils H. Rasmussen, Manish Bansal CYC. Business Dashboards: A Visual Catalog for Design and Deployment. Wiley; 2009. 304 p.

13. Erbasi A, Parlakkaya R. The Use of Analytic Hierarchy Process in the Balanced Scorecard: An Approach in a Hotel Firm. Bus Manag Rev [Internet]. 2012;2(2):23-37. Available from: http://www.businessjournalz.org/bmr

14. Eccles RG. The performance measurement manifesto. Harv Bus Rev. 1991;69(1):131-7.

15. Kaplan RS, Norton DP. Linking the Balanced Scorecard to Strategy. Calif Manage Rev [Internet]. 1996;39(1):53-79. Available from: http://journals.sagepub.com/doi/10.2307/41165876

16. Rigby DK, Bilodeau B. Management Tools and Trends 2005. Bain Company, Inc [Internet]. 2005; Available from: http://www.bain.com

17. Aidemark L-G. The Meaning of Balanced Scorecards in the Health Care Organisation. Financ Account Manag. 2003;

18. Končitíková G, Culík T, Pavla S. An application of Balanced Scorecard in healthcare organizations. Recent Adv Energy, Environ Financ Plan. 2014;197-202.

19. Chee W C. The Balanced Scorecard: A Potent Tool for Energizing and Focusing Healthcare Organization Management. Authors: J Healthc Manag Publ Coll Healthc Exec. 1998;

20. Oxford Dictionary [Internet]. [cited 2019 Jun 26]. Available from:

https://www.lexico.com/en/definition/key performan ce indicator
21. Jiang Y. Prioritizing and selecting KPIs : translate performance results into managerial actions in strategy making process. 2014;1-25.

22. Forkan ARM, Montori F, Georgakopoulos D, Jayaraman PP, Yavari A, Morshed A. An industrial IoT solution for evaluating workers' performance via activity recognition. Proc - Int Conf Distrib Comput Syst. 2019;2019-July:1393-403.

23. Meier H, Lagemann H, Morlock F, Rathmann C. Key performance indicators for assessing the planning and delivery of industrial services. In: Procedia CIRP. 2013. p. 99-104.

24. Parmenter D. Key performance indicators developing implementing and using winning KPIs. Wiley; 2001. 43 p.

25. Hsu C, Ohio T. Delphi Techniques Making Sense of Consensus. A peer-reviewed electronic J Pract Assess. 2007;12(10): Volume 12, ISSN 1531-7714.

26. Delbeca AL, Van de Ven AH, Gustafson DH. Group Techniques for Program Planning: A Guide to Nominal Group and Delphi Processes. Middleton, Wisconsin: Green Briar Press; 1986.

27. Digiesi S, Mossa G, Ranieri L, Rubino S, Engineering M. An integrated approach based on balanced scorecard and analytic hierarchy process for strategic evaluation of local healthcare agencies. (2007):1-7.

28. Marcela Porporato, Peter Tsasis, Luz Maria MV. Do hospital balanced scorecard measures reflect causeeffect relationships? ". Int J Product Perform Manag. 2017;66(3).

29. Chen X. Using the balanced scorecard to measure Chinese and Japanese hospital performance. 2006;19(4):339-50.

30. Zhang X, Gallagher K, Goh S. BI application: Dashboards for healthcare. 17th Am Conf Inf Syst 2011, AMCIS 2011 [Internet]. 2011;5:3898-902. Available from: http://www.scopus.com/inward/record.urle eid=2-s2.0$\underline{84870316889 \& \text { partnerlD }=40 \& m d 5=45 a 4760 a 81149393 d}$ 4daa2f7df08c207

31. Rahimi H, Kavosi Z, Shojaei P, Kharazmi E. Key performance indicators in hospital based on balanced scorecard model. J Heal Manag Informatics. 2016;4(1):17-24.

32. Samani DZ, Kohan MFZ. Framework for implementing balanced scorecard in hospitals. J Int Bus Entrep Dev. $2011 ; 5(4): 362-8$. 
33. Pan F-C. Identifying Key Performance Indicator of Balanced Scorecard by Analytic Hierarchy Process. In: Mcdm2004. 2004. p. 1-10.

34. Grigoroudis E, Orfanoudaki E, Zopounidis C. Strategic performance measurement in a healthcare organisation: A multiple criteria approach based on balanced scorecard. Omega [Internet]. 2012;40(1):104-19. Available from: http://dx.doi.org/10.1016/j.omega.2011.04.001

35. Khalifa M, Khalid P. Developing strategic health care key performance indicators: A case study on a tertiary care hospital. Procedia Comput Sci [Internet]. 2015;63(Icth):459-66. Available from: http://dx.doi.org/10.1016/j.procs.2015.08.368

36. 36. Health Metrics Network W. Framework and Standards for Country Health Information Systems. 2006. 